\title{
DRGANIA GIĘTNE W PLASZCZYŹNIE KÓł MODELOWANYCH UKŁADAMI PIERŚCIENIOWYMI Z WARSTWĄ SPRĘŻYSTĄ
}

\begin{abstract}
W pracy omówiono drgania giętne w płaszczyźnie kół modelowanych układami pierścieniowymi z podłożem sprężystym typu Winklera. Zaprezentowano równania drgań własnych modeli pierścieni Timoshenki i Bernoulliego z warstwą sprężystą typu Winklera. W równaniach uwzględniono zaproponowany trzyparametrowy model warstwy sprężystej. Następnie wyprowadzono równanie częstości własnych wymienionych modeli oraz podano równanie form własnych. Zasadnicza część pracy dotyczy oceny wpływu głębokości pierścienia na wyniki rozwiązań analitycznych otrzymanych $\mathrm{z}$ proponowanych modeli. W procesie dostrajania współczynników modeli analitycznych wykorzystano wyniki rozwiązań numerycznych opartych na metodzie elementów skończonych. Otrzymane wyniki symulacji zweryfikowano doświadczalnie na wybranych obiektach. Ustalono przypadki pierścieni, dla których korzystne jest stosowanie zaproponowanych modeli analitycznych.
\end{abstract}

Słowa kluczowe: drgania giętne w płaszczyźnie, podłoże sprężyste Winklera

\section{Wprowadzenie}

Problematyka modelowania drgań układów kołowo-symetrycznych układami pierścieniowymi z warstwą sprężystą jest przedmiotem zainteresowania wielu badaczy i ośrodków badawczo-rozwojowych [1-7]. Wynika to z faktu, że w przypadku analizy zagadnień drgań giętnych w płaszczyźnie układów typu koła kolejowe i zębate korzystnie jest stosować wymienione analityczne modele pierścieniowe $\mathrm{z}$ warstwą sprężystą $[2,4]$. Podstawy teoretyczne dotyczące analizy i pomiarów drgań układów ciągłych z uwzględnieniem metody elementów skończonych (MES) omówiono w pracy [8]. W publikacjach [5,7] rozważano przydatność zaproponowanych modeli analitycznych w symulacji drgań giętnych w płaszczyźnie kół kolejowych i kół z ogumieniem pełnym. Artykuł [1] dotyczy z kolei analizy drgań giętnych kół samochodowych. W pracach $[2,4]$ omówiono drgania giętne w płaszczyźnie kół zębatych, stosując modele analityczne i numeryczne MES. W publikacji [3] analizowano przydatność modelu analitycznego pierścienia cienkiego z trzyparametrową warstwą sprężystą w procesie symulacji

\footnotetext{
1 Autor do korespondencji/corresponding author: Stanisław Noga, Politechnika Rzeszowska, al. Powstańców Warszawy 12, 35-959 Rzeszów, Polska, tel.: (17) 8651639, e-mail: noga@ prz.edu.pl
} 
drgań układów kołowo-symetrycznych. Podobny problem, odnoszący się do modelu tzw. pierścienia grubego, dyskutowano w referacie [6]. W pracach [2, 4], omówiono podstawy teoretyczne dotyczące równań drgań giętnych w płaszczyźnie układów pierścieni cienkich (teoria Bernoulliego) i grubych (teoria Timoshenki) z trzyparametrową warstwą sprężystą typu Winklera. W niniejszej pracy omówiono drgania giętne w płaszczyźnie kół modelowanych układami pierścieniowymi z podłożem sprężystym. Zasadnicza część pracy dotyczy oceny wpływu głębokości pierścienia na wyniki rozwiązań otrzymanych z proponowanych modeli analitycznych. W procesie badawczym wykorzystano rezultaty badań doświadczalnych i wyniki rozwiązań MES.

\section{Sformułowanie zagadnienia}

Model mechaniczny rozważanych układów zawiera płaski pierścień kołowo-symetryczny współpracujący z trzyparametrowym podłożem sprężystym typu Winklera $[2,4]$. W rozważaniach teoretycznych założono prostokątny jednorodny przekrój poprzeczny pierścienia i podłoża. Przyjmuje się, że pierścień i podłoże stanowią układ doskonale sprężysty, a $R$ to promień linii środkowej pierścienia.
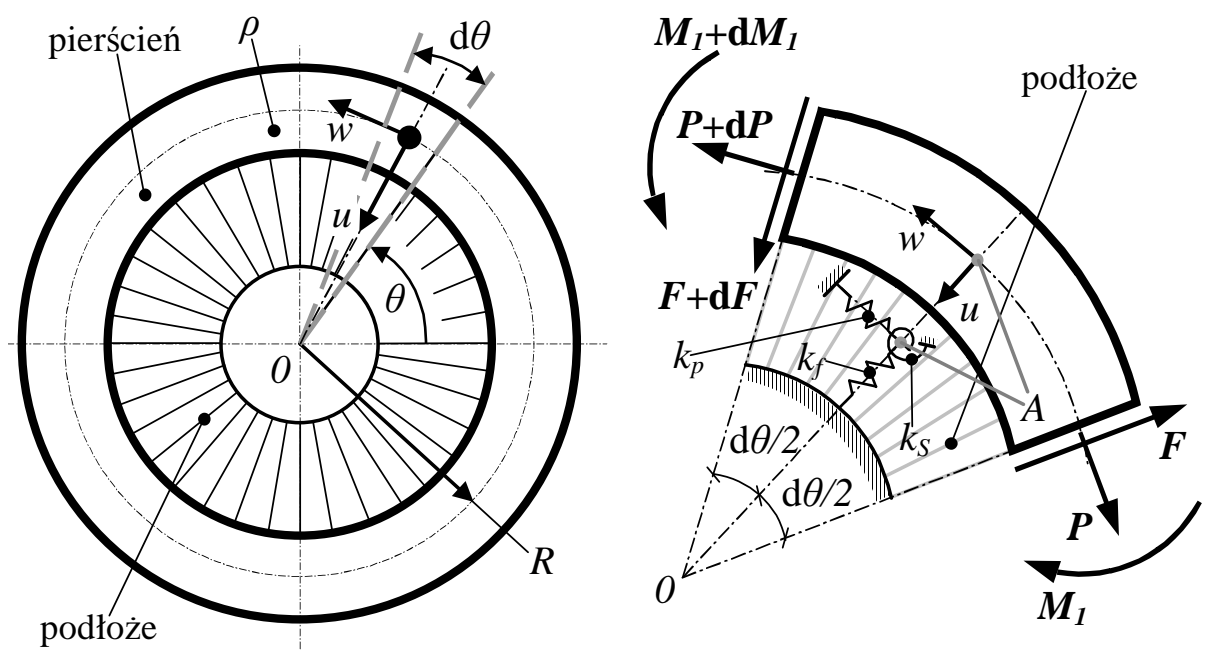

Rys. 1. Model układu pierścienia z warstwą sprężystą Winklera

Fig. 1. Physical model of a ring with Winkler foundation

Zakłada się, że nieskończenie mały element pierścienia (rys. 1.) wyznaczony przez kąt $\theta$ przemieszcza się w kierunku promieniowym $u(\theta, t)$ i obwodowym $w(\theta, t)$. W modelu matematycznym podłoża uwzględnia się dodatkowo przemieszczenie kątowe $\mathrm{w}$ płaszczyźnie wynikające $\mathrm{z}$ obrotu w płaszczyźnie przekroju poprzecznego pierścienia podczas deformacji $[2,4]$. Przyjmuje się małe 
przemieszczenia na wymienionych kierunkach. W proponowanym modelu matematycznym podłoża współczynniki $k_{f}$ i $k_{p}$ reprezentują sztywność promieniową i obwodową podłoża, a trzeci współczynnik $k_{S}$ uwzględnia sztywność obrotową podłoża, ze względu na wspomniany obrót przekrojów poprzecznych pierścienia w czasie drgań giętnych w płaszczyźnie. W przypadku gdy rozpatrywany jest tzw. pierścień gruby stosuje się teorię Timoshenki [2], a równanie drgań własnych giętnych w płaszczyźnie układu, w funkcji przemieszczenia promieniowego przyjmuje formę $[2,4]$ :

$$
\begin{aligned}
& \frac{\partial^{6} u}{\partial \theta^{6}}+\left(2-k_{f} \frac{R^{2}}{k A G}-k_{S} \frac{R^{2}}{E I_{1}}\right) \frac{\partial^{4} u}{\partial \theta^{4}}+\left(1+k_{p} \frac{R^{2}}{k A G}-2 k_{S} \frac{R^{2}}{E I_{1}}+k_{f} k_{S} \frac{R^{4}}{k A G E I_{1}}+\right. \\
& \left.+k_{f} \frac{R^{4}}{E I_{1}}\right) \frac{\partial^{2} u}{\partial \theta^{2}}-\left(k_{S} \frac{R^{2}}{E I_{1}}+k_{p} k_{S} \frac{R^{4}}{k A G E I_{1}}+k_{p} \frac{R^{4}}{E I_{1}}\right) u-\left(\frac{\rho R^{2}}{E}+\frac{\rho R^{2}}{k G}\right) \frac{\partial^{6} u}{\partial \theta^{4} \partial t^{2}}+ \\
& +\frac{\rho^{2} R^{4}}{k G E} \frac{\partial^{6} u}{\partial \theta^{2} \partial t^{4}}+\left(-2 \frac{\rho R^{2}}{E}+k_{f} \frac{\rho R^{4}}{k A G E}+\frac{\rho R^{2}}{k G}+k_{S} \frac{\rho R^{4}}{k G E I_{1}}+\frac{\rho A R^{4}}{E I_{1}}\right) \frac{\partial^{4} u}{\partial \theta^{2} \partial t^{2}}+ \\
& -\frac{\rho^{2} R^{4}}{k G E} \frac{\partial^{4} u}{\partial t^{4}}-\left(\frac{\rho R^{2}}{E}+k_{p} \frac{\rho R^{4}}{k A G E}+k_{S} \frac{\rho R^{4}}{k G E I_{1}}+\frac{\rho A R^{4}}{E I_{1}}\right) \frac{\partial^{2} u}{\partial t^{2}}=0
\end{aligned}
$$

gdzie: $E$ - moduł Younga,

$G$ - moduł Kirchhoffa,

$I_{1}$ - geometryczny moment bezwładności przekroju poprzecznego pierścienia,

$\rho$ - gęstość masy pierścienia,

$A$ - pole przekroju poprzecznego pierścienia,

$k$ - współczynnik kształtu przekroju.

W przypadku tzw. pierścienia cienkiego stosuje się teorię Bernoulliego i równanie (1) przyjmuje postać [2, 4]:

$$
\begin{aligned}
& \frac{E I_{1}}{R^{3}}\left(\frac{\partial^{6} u}{\partial \theta^{6}}+2 \frac{\partial^{4} u}{\partial \theta^{4}}+\frac{\partial^{2} u}{\partial \theta^{2}}\right)-\frac{k_{S}}{R}\left(\frac{\partial^{4} u}{\partial \theta^{4}}+2 \frac{\partial^{2} u}{\partial \theta^{2}}+u\right)+\left(k_{f} \frac{\partial^{2} u}{\partial \theta^{2}}-k_{p} u\right) R+ \\
& +\rho A R \frac{\partial^{2}}{\partial t^{2}}\left(\frac{\partial^{2} u}{\partial \theta^{2}}-u\right)=0
\end{aligned}
$$

Warto zauważyć, że równanie (2) ma znacznie prostszą postać niż zależność (1). Wynika to z faktu, że w przypadku pierścieni cienkich, przy formułowaniu równań drgań giętnych w płaszczyźnie pomija się wpływ odkształcenia postaciowego $(k=0)$ i bezwładności obrotowej pierścienia [2]. 


\section{Rozwiązania teoretyczne drgań własnych}

Rozwiązania ogólnego równań (1) i (2) poszukuje się w postaci:

$$
u(\theta, t)=U(\theta) e^{i \omega t}
$$

gdzie: $\omega$-częstość własna,

$i=\sqrt{-1}-$ jednostka urojona.

Po podstawieniu rozwiązania (3) do równania (1) otrzymuje się zależność:

$$
\begin{aligned}
& \frac{\mathrm{d}^{6} U}{\mathrm{~d} \theta^{6}}+\left(2-b_{0} k_{f}-k_{S} \frac{a_{0}}{R^{2}}\right) \frac{\mathrm{d}^{4} U}{\mathrm{~d} \theta^{4}}+\left(1+b_{0} k_{p}-2 k_{S} \frac{a_{0}}{R^{2}}+k_{f} k_{S} \times\right. \\
& \left.\times \frac{h_{0}}{\rho I_{1}}+k_{f} a_{0}\right) \frac{\mathrm{d}^{2} U}{\mathrm{~d} \theta^{2}}-\left(k_{S} \frac{a_{0}}{R^{2}}+k_{p} k_{S} \frac{h_{0}}{\rho I_{1}}+k_{p} a_{0}\right) U+\left(c_{0}+d_{0}\right) \times \\
& \times \omega^{2} \frac{\mathrm{d}^{4} U}{\mathrm{~d} \theta^{4}}+c_{0} d_{0} \omega^{4} \frac{\mathrm{d}^{2} U}{\mathrm{~d} \theta^{2}}-c_{0} d_{0} \omega^{4} U-\left(-2 c_{0}+k_{f} h_{0}+d_{0}+k_{S} \frac{h_{0} A}{I_{1}}+\right. \\
& \left.+\rho A a_{0}\right) \omega^{2} \frac{\mathrm{d}^{2} U}{\mathrm{~d} \theta^{2}}+\left(c_{0}+k_{p} h_{0}+k_{S} \frac{h_{0} A}{I_{1}}+\rho A a_{0}\right) \omega^{2} U=0
\end{aligned}
$$

gdzie:

$$
a_{0}=\frac{R^{4}}{E I_{1}}, \quad b_{0}=\frac{R^{2}}{k A G}, \quad c_{0}=\frac{\rho R^{2}}{E}, \quad d_{0}=\frac{\rho R^{2}}{k G}, \quad h_{0}=\frac{\rho R^{4}}{k E A G}
$$

W przypadku podstawienia równania (3) do wzoru (2):

$$
\begin{aligned}
\frac{\mathrm{d}^{6} U}{\mathrm{~d} \theta^{6}}+\left(2-h_{1}\right) \frac{\mathrm{d}^{4} U}{\mathrm{~d} \theta^{4}}+\left(1-2 h_{1}+a_{1}\right) \frac{\mathrm{d}^{2} U}{\mathrm{~d} \theta^{2}} & -\left(c_{1}+h_{1}\right) U+ \\
& -\omega^{2} b_{1}\left(\frac{\mathrm{d}^{2} U}{\mathrm{~d} \theta^{2}}-U\right)=0
\end{aligned}
$$

gdzie:

$$
a_{1}=\frac{k_{f} R^{4}}{E I_{1}}, \quad b_{1}=\frac{\rho A R^{4}}{E I_{1}}, \quad c_{1}=\frac{k R^{4}}{E I_{1}}, \quad h_{1}=\frac{k_{S} R^{2}}{E I_{1}}
$$


Rozwiązanie ogólne równań (4) i (6) jest przewidywane w postaci [2, 8]:

$$
U(\theta)=\sum_{j=1}^{3} C_{j n} \sin \left(n \theta+\varphi_{j n}\right), \quad n=2,3, \ldots
$$

gdzie: $C_{j n}, \varphi_{j n}-$ stałe.

Po podstawieniu równania (8) do równań (4) i (6) otrzymuje się tzw. równania częstości. W przypadku równania (4) równanie częstości przyjmuje formę:

$$
\begin{array}{r}
-c_{0} d_{0}\left(n^{2}+1\right) \omega_{n}^{4}+\left[\left(c_{0}+d_{0}\right) n^{4}+\left(-2 c_{0}+k_{f} h_{0}+d_{0}+k_{S} \frac{h_{0} A}{I_{1}}+\rho A a_{0}\right) \times\right. \\
\left.\times n^{2}+\left(c_{0}+k_{p} h_{0}+k_{S} \frac{h_{0} A}{I_{1}}+\rho A a_{0}\right)\right] \omega_{n}^{2}-n^{6}+\left(2-b_{0} k_{f}-k_{S} \frac{a_{0}}{R^{2}}\right) n^{4}+ \\
-\left(1+b_{0} k_{p}-2 k_{S} \frac{a_{0}}{R^{2}}+k_{f} k_{S} \frac{h_{0}}{\rho I_{1}}+k_{f} a_{0}\right) n^{2}-\left(k_{S} \frac{a_{0}}{R^{2}}+\right. \\
\left.+k_{p} k_{S} \frac{h_{0}}{\rho I_{1}}+k_{p} a_{0}\right)=0
\end{array}
$$

Równanie (9) jest równaniem kwadratowym ze względu na $\omega_{n}^{2}$. Oznacza to, że każdemu $n$ odpowiadają dwie wartości częstości własnych. Niższe wartości odnoszą się do częstości własnych drgań giętnych w płaszczyźnie [2, 4]. W przypadku równania (6) równanie częstości przyjmuje postać:

$$
\omega_{n}^{2}=\frac{n^{6}-\left(2-h_{1}\right) n^{4}+\left(1-2 h_{1}+a_{1}\right) n^{2}+\left(c_{1}+h_{1}\right)}{b_{1}\left(n^{2}+1\right)}, \quad n=2,3, \ldots
$$

Istnieje szczególny przypadek rozwiązania równań (9) i (10). Mianowicie po podstawieniu do wymienionych równań $n=1$, otrzymuje się oscylacje związane tylko z przemieszczeniem w płaszczyźnie pierścienia, bez jego deformacji (deformuje się tylko warstwa sprężysta). Dla dowolnego $n>1$ pierścień (gruby lub cienki) odkształca się zgodnie z równaniem [2, 4]:

$$
u_{n}(\theta, t)=C_{j n} \sin \left(n \theta+\varphi_{j n}\right) e^{i \omega_{n} t}
$$

przy czym stałe $C_{j n}$ i $\varphi_{j n}$ wyznacza się z warunków początkowych układu. 


\section{Modele MES układów pierścieniowych}

W bieżącym rozdziale zostaną omówione modele MES rozważanych układów pierścieniowych. Modele te otrzymuje się z dyskretyzacji modelu ciągłego układu rzeczywistego. Analizie poddano obiekty o geometrii pokazanej na rys. 2. Rozważono sześć przypadków układów pierścieniowych. W tabeli 1. zamieszczono dane techniczne badanych układów, przy czym $h$ to grubość pierścienia wzdłuż promienia, a $v$ - współczynnik Poissona. Pozostałe wielkości zdefiniowano na rys. 2. bądź w zależności (1). Każdy rozważany układ składa się $\mathrm{z}$ obrzeża modelowanego pierścieniem sprężystym oraz tarczy traktowanej jako masowe podłoże sprężyste.

a)

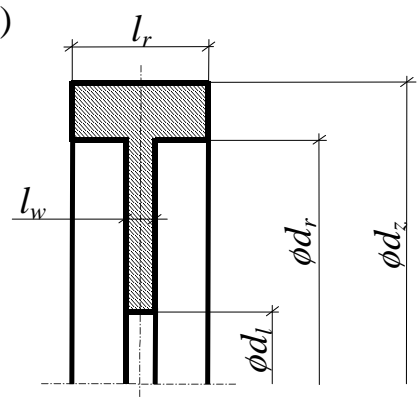

b)

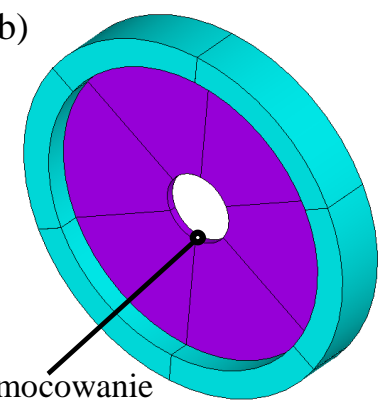

Rys. 2. Model geometryczny rozważanych układów: a) wymiary geometryczne, b) widok modelu

Fig. 2. Geometrical model of a discussed systems: a) geometric dimensions, b) view of the model

Równania drgań własnych układu dyskretnego korzystnie jest zapisać w postaci macierzowej $[2,8]$ :

$$
\mathbf{M u ̈}+\mathbf{K u}=\mathbf{0}
$$

gdzie: $\mathbf{M}-$ macierz bezwładności w układzie globalnym,

$\mathbf{K}$ - macierz sztywności w układzie globalnym,

$\ddot{\mathbf{u}}$ - wektor przyspieszeń węzłowych,

u - wektor przemieszczeń węzłowych.

Częstości drgań własnych w tym przypadku otrzymuje się, rozwiązując zagadnienie własne:

$$
\left(\mathbf{K}-\omega^{2} \mathbf{M}\right) \overline{\mathbf{u}}=0
$$

gdzie: $\omega$-wspomniana wcześniej częstość drgań własnych,

$\overline{\mathbf{u}}$ - wektor własny (postać drgań własnych). 
Tabela 1. Dane techniczne analizowanych układów

Table 1. Parameters characterizing discussed systems

\begin{tabular}{|c|c|c|c|c|c|c|c|c|c|c|}
\hline Lp. & $\begin{array}{l}d_{z}, \\
\mathrm{~m}\end{array}$ & $\begin{array}{c}d_{w}, \\
\mathrm{~m}\end{array}$ & $\begin{array}{l}\text { h, } \\
\mathrm{m}\end{array}$ & $\begin{array}{c}\rho, \\
\mathrm{kg} / \mathrm{m}^{3}\end{array}$ & $\begin{array}{l}R, \\
\mathrm{~m}\end{array}$ & $\begin{array}{c}d_{1}, \\
\mathrm{~m}\end{array}$ & $\begin{array}{l}l_{r}, \\
\mathrm{~m}\end{array}$ & $\begin{array}{l}l_{w}, \\
\mathrm{~m}\end{array}$ & $\begin{array}{l}E, \\
\mathrm{~Pa}\end{array}$ & $v$ \\
\hline 1 & 0,179 & 0,171 & 0,004 & \multirow{6}{*}{$7,85 \cdot 10^{3}$} & \multirow{6}{*}{0,0875} & \multirow{6}{*}{0,02} & \multirow{6}{*}{0,008} & \multirow{6}{*}{0,002} & \multirow{6}{*}{$2,1 \cdot 10^{11}$} & \multirow{6}{*}{0,28} \\
\hline 2 & 0,180 & 0,170 & 0,005 & & & & & & & \\
\hline 3 & 0,181 & 0,169 & 0,006 & & & & & & & \\
\hline 4 & 0,183 & 0,167 & 0,008 & & & & & & & \\
\hline 5 & 0,187 & 0,163 & 0,012 & & & & & & & \\
\hline 6 & 0,191 & 0,159 & 0,016 & & & & & & & \\
\hline
\end{tabular}

a)

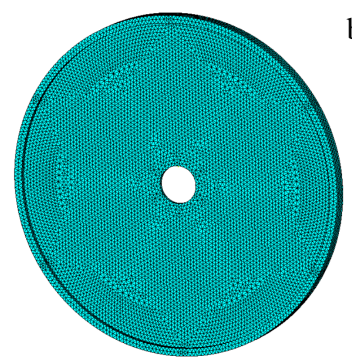

d)

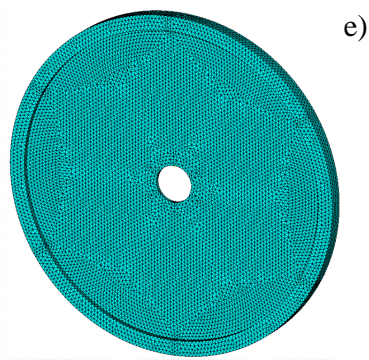

b)
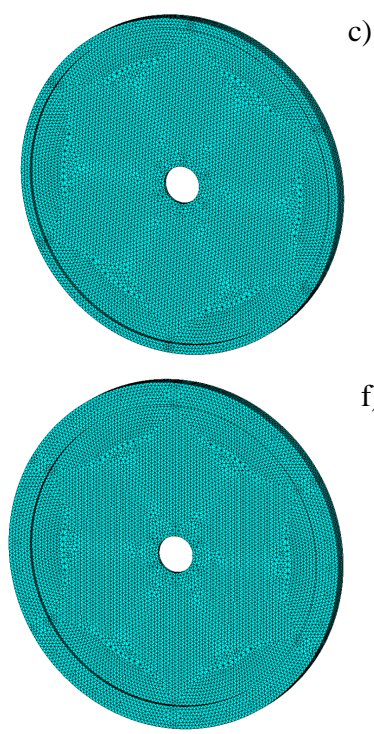

c)

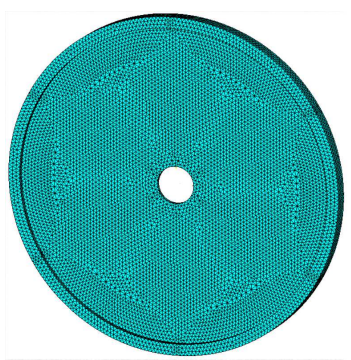

f)

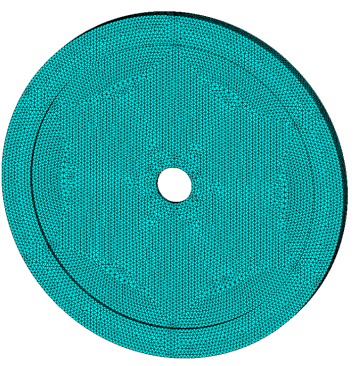

Rys. 3. Modele MES układów po rozwinięciu: a) model obiektu nr 1, b) model obiektu nr 2, c) model obiektu nr 3, d) model obiektu nr 4, e) model obiektu nr 5, f) model obiektu nr 6

Fig. 3. FE models of the systems after evaluation: a) model of the object no. 1, b) model of the object no. 2, c) model of the object no. 3, d) model of the object no. 4 , e) model of the object no. 5, f) model of the object no. 6

W obliczeniach numerycznych do rozwiązania zagadnienia własnego (11) stosuje się metodę blokową Lanczosa [2,8]. W pierwszej kolejności porównano wyniki rozwiązań analitycznych z rozwiązaniami numerycznymi MES. Następnie dla wybranych przypadków obiektów wyniki z modeli analitycznych i numerycznych odniesiono do rezultatów badań doświadczalnych. Jakość zaproponowanych modeli analitycznych i numerycznych MES ustala się, wyznaczając tzw. błąd względny częstości, określony zależnością [2]: 


$$
\varepsilon=\left(\omega^{f}-\omega^{e}\right) / \omega^{e} \times 100, \%
$$

gdzie: $\omega^{e}$ - referencyjna wartość częstości własnej drgań giętnych,

$\omega^{f}$ - wartość częstości własnej drgań z modelu.

Dla każdego rozważanego przypadku opracowano model MES w środowisku ANSYS APDL. W procesie nakładania siatki stosowano element czworościenny dziesięciowęzłowy (solid187) o trzech stopniach swobody w każdym węźle. Przyjęto, że długość krawędzi elementu nie przekracza grubości tarczy modelującej podłoże sprężyste w danym układzie [2, 8]. Przy opracowywaniu modeli MES wykorzystano właściwości cyklicznej symetrii rozważanych obiektów. Każdy model MES stanowi jedną szóstą modelowanych układów. Na rysunku 3. pokazano modele MES analizowanych obiektów po rozwinięciu do procesu wizualizacji wyników obliczeń.

\section{Analiza numeryczna}

W niniejszym rozdziale omówiono wyniki rozwiązań analitycznych i numerycznych dla modeli analizowanych układów. Dla każdego przypadku modelu wyznaczono siedem pierwszych częstości drgań własnych giętnych w płaszczyźnie i odpowiadających im form własnych. Ze względu na to, że modele analityczne nie uwzględniają masy warstwy sprężystej, zadowalające rezultaty uzyskuje się przy zmianie masy pierścieni w modelach analitycznych układów. W tabeli 2. podano wartości współczynników zastępczej gęstości materiałowej pierścieni modeli analitycznych rozważanych obiektów, przy których uzyskano zadowalające wyniki. Wartości te wyznaczono w symulacji numerycznej dla modeli Timoshenki, a następnie wykorzystywano w modelach Bernoulliego. Podobnie, wartości współczynników $k_{f}, k_{p}$ i $k_{S}$ wyznaczono w symulacji numerycznej, przy czym aby uzyskać satysfakcjonujący wynik, dla każdego modelu analitycznego należało wyznaczyć osobny zbiór wartości współczynników.

Tabela 2. Współczynnik zastępczej gęstości materiałowej pierścieni

Table 2. Ring substitute mass density

\begin{tabular}{|c|c|}
\hline Lp. & $\begin{array}{c}\rho_{z}, \\
\mathrm{~kg} / \mathrm{m}^{3}\end{array}$ \\
\hline 1 & $94 \cdot 10^{3}$ \\
\hline 2 & $95 \cdot 10^{3}$ \\
\hline 3 & $95 \cdot 10^{3}$ \\
\hline 4 & $93 \cdot 10^{3}$ \\
\hline 5 & $885 \cdot 10^{3}$ \\
\hline 6 & $835 \cdot 10^{3}$ \\
\hline
\end{tabular}


W tabeli 3. podano wartości częstotliwości drgań własnych giętnych w płaszczyźnie, uzyskane z modeli MES analizowanych obiektów. Rezultaty te wykorzystano jako dane referencyjne do wyznaczenia współczynników $\rho_{z}, k_{f}, k_{p}$ i $k_{S}$ modeli analitycznych obiektów. W tabeli 4. pokazano wartości częstotliwości drgań własnych giętnych rozważanych układów oraz wartości współczynników $k_{f}, k_{p}, k_{s}$ otrzymane z modeli Timoshenki (pierścienie grube).

Tabela 3. Częstotliwości własne rozważanych układów $\omega_{n}, \mathrm{~Hz}$ (rozwiązanie MES)

Table 3. Natural frequencies of the considered systems $\omega_{n}, \mathrm{~Hz}$ (FE solutions)

\begin{tabular}{|c|c|c|c|c|c|c|c|c|c|c|}
\hline \multirow{2}{*}{ Lp. } & \multirow{2}{*}{$\begin{array}{c}k_{f}, \\
\mathrm{~N} / \mathrm{m}^{2}\end{array}$} & \multirow{2}{*}{$\begin{array}{c}k_{p} \\
\mathrm{~N} / \mathrm{m}^{2}\end{array}$} & \multirow{2}{*}{$\begin{array}{c}k s, \\
\mathrm{~N} / \mathrm{m}\end{array}$} & \multicolumn{7}{|c|}{$n$} \\
\hline & & & & 2 & 3 & 4 & 5 & 6 & 7 & 8 \\
\hline 1 & - & - & - & 11135 & 17854 & 22886 & 27355 & 31489 & 35385 & 39105 \\
\hline 2 & - & - & - & 10792 & 17195 & 21963 & 26186 & 30098 & 33808 & 37387 \\
\hline 3 & - & - & - & 10475 & 16603 & 21156 & 25195 & 28962 & 32573 & 36104 \\
\hline 4 & - & - & - & 9916 & 15597 & 19834 & 23645 & 27280 & 30863 & 34472 \\
\hline 5 & - & - & - & 9038 & 14141 & 18091 & 21833 & 25607 & 29518 & 33611 \\
\hline 6 & - & - & - & 8393 & 13199 & 17141 & 21084 & 25218 & 29594 & 34207 \\
\hline
\end{tabular}

Tabela 4. Częstotliwości własne rozważanych układów $\omega_{n}, \mathrm{~Hz}$ (model Timoshenki)

Table 4. Natural frequencies of the considered systems $\omega_{n}, \mathrm{~Hz}$ (thick ring solution)

\begin{tabular}{|c|c|c|c|c|c|c|c|c|c|c|}
\hline \multirow{2}{*}{ Lp. } & \multirow{2}{*}{$\begin{array}{c}k_{f}, \\
\mathrm{~N} / \mathrm{m}^{2}\end{array}$} & \multirow{2}{*}{$\begin{array}{c}k_{p} \\
\mathrm{~N} / \mathrm{m}^{2}\end{array}$} & \multirow{2}{*}{$\begin{array}{c}k_{S}, \\
\mathrm{~N} / \mathrm{m}\end{array}$} & \multicolumn{7}{|c|}{$n$} \\
\hline & & & & 2 & 3 & 4 & 5 & 6 & 7 & 8 \\
\hline 1 & $15 \cdot 10^{9}$ & $6 \cdot 10^{6}$ & $175 \cdot 10^{8}$ & 11997 & 16304 & 20819 & 25454 & 30161 & 34911 & 39691 \\
\hline 2 & $17 \cdot 10^{9}$ & $6 \cdot 10^{6}$ & $13 \cdot 10^{8}$ & 11520 & 15851 & 20378 & 25010 & 29702 & 34431 & 39183 \\
\hline 3 & $185 \cdot 10^{9}$ & $6 \cdot 10^{6}$ & $112 \cdot 10^{8}$ & 11132 & 15510 & 20072 & 24723 & 29424 & 34155 & 38904 \\
\hline 4 & $224 \cdot 10^{9}$ & $6 \cdot 10^{6}$ & $18 \cdot 10^{7}$ & 10561 & 14530 & 18681 & 22932 & 27243 & 31593 & 35972 \\
\hline 5 & $228 \cdot 10^{9}$ & $6 \cdot 10^{6}$ & $18 \cdot 10^{7}$ & 9390 & 13469 & 17698 & 21996 & 26340 & 30722 & 35140 \\
\hline 6 & $223 \cdot 10^{9}$ & $6 \cdot 10^{6}$ & $16 \cdot 10^{7}$ & 8602 & 12686 & 16916 & 21227 & 25613 & 30072 & 34605 \\
\hline
\end{tabular}

Tabela 5. zawiera wyniki (wartości częstotliwości drgań własnych giętnych oraz współczynników $k_{f}, k_{p}, k_{S}$ ) otrzymane z modeli Bernoulliego (pierścienie cienkie).

Kolejne tabele zawierają błędy częstości (12) wynikające z porównania otrzymanych rozwiązań analitycznych z rezultatami uzyskanymi z modeli MES układów, przy czym - jak wspomniano wcześniej - wyniki rozwiązań MES traktowano jako dane referencyjne. W tabeli 6. zamieszczono stosowne wartości błędu częstości wynikające z porównania wyników z modeli Timoshenki z wynikami z modeli MES. Otrzymane wartości błędów są dla rozważanych przypadków obiektów zadowalające (dla każdej częstości bezwzględne wartości błędów poniżej 91\%). Jedynie w odniesieniu do pierwszego obiektu zauważa się dla dwóch częstości błąd powyżej $8 \%$. 
Tabela 5. Częstotliwości własne rozważanych układów $\omega_{n}, \mathrm{~Hz}$ (model Bernoulliego)

Table 5. Natural frequencies of the considered systems $\omega_{n}, \mathrm{~Hz}$ (thin ring solution)

\begin{tabular}{|c|c|c|c|c|c|c|c|c|c|c|}
\hline \multirow{2}{*}{ Lp. } & \multirow{2}{*}{$\begin{array}{c}k_{f}, \\
\mathrm{~N} / \mathrm{m}^{2}\end{array}$} & \multirow{2}{*}{$k_{p}}$, & \multirow{2}{*}{$k_{S}}$, & \multicolumn{7}{|c|}{$n$} \\
\cline { 5 - 10 } & & $\mathrm{N} / \mathrm{m}^{2}$ & & 2 & 3 & 4 & 5 & 6 & 7 & 8 \\
\hline 1 & $1405 \cdot 10^{9}$ & $6 \cdot 10^{6}$ & $235 \cdot 10^{6}$ & 11890 & 16514 & 21359 & 26335 & 31404 & 36552 & 41774 \\
\hline 2 & $17 \cdot 10^{9}$ & $6 \cdot 10^{6}$ & $264 \cdot 10^{6}$ & 11501 & 15824 & 20380 & 25092 & 29926 & 34870 & 39924 \\
\hline 3 & $195 \cdot 10^{9}$ & $6 \cdot 10^{6}$ & $292 \cdot 10^{6}$ & 11183 & 15322 & 19709 & 24277 & 29000 & 33869 & 38888 \\
\hline 4 & $244 \cdot 10^{9}$ & $6 \cdot 10^{6}$ & $309 \cdot 10^{6}$ & 10696 & 14367 & 18333 & 22565 & 27051 & 31792 & 36802 \\
\hline 5 & $301 \cdot 10^{9}$ & $6 \cdot 10^{6}$ & $314 \cdot 10^{6}$ & 9733 & 12889 & 16503 & 20624 & 25275 & 30483 & 36275 \\
\hline 6 & $323 \cdot 10^{9}$ & $6 \cdot 10^{6}$ & $228 \cdot 10^{6}$ & 8697 & 11289 & 14648 & 18931 & 24176 & 30393 & 37582 \\
\hline
\end{tabular}

Tabela 6. Błąd częstości $\varepsilon_{n}, \%$ (porównanie rozwiązań z modeli Timoshenki z wynikami MES)

Table 6 . Frequency error $\varepsilon_{n}, \%$ (comparison of the thick ring solution with the FE solutions)

\begin{tabular}{|c|c|c|c|c|c|c|c|c|c|c|}
\hline \multirow{2}{*}{ Lp. } & \multirow{2}{*}{$\begin{array}{c}k_{f}, \\
\mathrm{~N} / \mathrm{m}^{2}\end{array}$} & \multirow{2}{*}{$\begin{array}{c}k_{p} \\
\mathrm{~N} / \mathrm{m}^{2}\end{array}$} & \multirow{2}{*}{$\begin{array}{c}k_{S} \\
\mathrm{~N} / \mathrm{m}\end{array}$} & \multicolumn{7}{|c|}{$n$} \\
\hline & & & & 2 & 3 & 4 & 5 & 6 & 7 & 8 \\
\hline 1 & $15 \cdot 10^{9}$ & $6 \cdot 10^{6}$ & $175 \cdot 10^{8}$ & 774 & -868 & -903 & -695 & -421 & -134 & 15 \\
\hline 2 & $17 \cdot 10^{9}$ & $6 \cdot 10^{6}$ & $13 \cdot 10^{8}$ & 674 & -782 & -722 & -449 & -131 & 184 & 48 \\
\hline 3 & $185 \cdot 10^{9}$ & $6 \cdot 10^{6}$ & $112 \cdot 10^{8}$ & 627 & -659 & -513 & -187 & 16 & 486 & 776 \\
\hline 4 & $224 \cdot 10^{9}$ & $6 \cdot 10^{6}$ & $18 \cdot 10^{7}$ & 651 & -684 & -582 & -302 & -014 & 237 & 435 \\
\hline 5 & $228 \cdot 10^{9}$ & $6 \cdot 10^{6}$ & $18 \cdot 10^{7}$ & 389 & -475 & -217 & 075 & 286 & 408 & 455 \\
\hline 6 & $223 \cdot 10^{9}$ & $6 \cdot 10^{6}$ & $16 \cdot 10^{7}$ & 248 & -389 & -131 & 068 & 156 & 161 & 116 \\
\hline
\end{tabular}

W tabeli 7. zamieszczono wartości błędu częstości wynikające z porównania rezultatów z modeli Bernoulliego ze stosownymi rozwiązaniami MES. W tym przypadku zauważa się gorsze dopasowanie modeli obiektów $\operatorname{nr} 5$ i 6 . Wyniki dla obiektu nr 5 są dopuszczalne (dla dwóch częstości bezwzględna wartość błędu częstości mieści się w przedziale 8-9\%). W przypadku obiektu nr 6 dla trzech częstości obserwuje się błąd (wartość bezwzględna) powyżej 10\%, a dla jednej powyżej 9\%, co nie jest do zaakceptowania.

Tabela 7. Błąd częstości $\varepsilon n$, \% (porównanie rozwiązań z modeli Bernoulliego z wynikami MES)

Table 7. Frequency error $\varepsilon_{n}, \%$ (comparison of the thin ring solution with the FE solutions)

\begin{tabular}{|c|c|c|c|c|c|c|c|c|c|c|}
\hline \multirow{2}{*}{ Lp. } & \multirow{2}{*}{$\begin{array}{c}k_{f} \\
\mathrm{~N} / \mathrm{m}^{2}\end{array}$} & \multirow{2}{*}{$\begin{array}{c}k_{p}, \\
\mathrm{~N} / \mathrm{m}^{2}\end{array}$} & \multirow{2}{*}{$\begin{array}{c}k s, \\
\mathrm{~N} / \mathrm{m}\end{array}$} & \multicolumn{7}{|c|}{$n$} \\
\hline & & & & 2 & 3 & 4 & 5 & 6 & 7 & 8 \\
\hline 1 & $1405 \cdot 10^{9}$ & $6 \cdot 10^{6}$ & $235 \cdot 10^{6}$ & 678 & -751 & -667 & -373 & -027 & 33 & 683 \\
\hline 2 & $17 \cdot 10^{9}$ & $6 \cdot 10^{6}$ & $264 \cdot 10^{6}$ & 657 & -797 & -721 & -418 & -057 & 314 & 679 \\
\hline 3 & $195 \cdot 10^{9}$ & $6 \cdot 10^{6}$ & $292 \cdot 10^{6}$ & 676 & -772 & -684 & -364 & 013 & 398 & 771 \\
\hline 4 & $244 \cdot 10^{9}$ & $6 \cdot 10^{6}$ & $309 \cdot 10^{6}$ & 787 & -789 & -757 & -457 & -084 & 301 & 676 \\
\hline 5 & $301 \cdot 10^{9}$ & $6 \cdot 10^{6}$ & $314 \cdot 10^{6}$ & 769 & -885 & -878 & -554 & -13 & 327 & 792 \\
\hline 6 & $323 \cdot 10^{9}$ & $6 \cdot 10^{6}$ & $228 \cdot 10^{6}$ & 362 & -145 & -145 & -102 & -413 & 27 & 986 \\
\hline
\end{tabular}


Analizując otrzymane rezultaty, zauważa się zadowalającą zgodność obu modeli analitycznych z wynikami MES dla pierwszych pięciu obiektów. Biorąc pod uwagę wpływ głębokości pierścieni $h$ w relacji do promieni linii środkowej $R$, można zauważyć, że dla wartości parametru $h / R$ poniżej 014 występuje zadowalająca zgodność obu modeli analitycznych z wynikami MES (obiekty nr 1-5).

\section{Weryfikacja doświadczalna}

Otrzymane w symulacji modele analityczne i numeryczne MES zweryfikowano badaniami doświadczalnymi.

Rys. 4. Badania doświadczalne

Fig. 4. Experimental verification

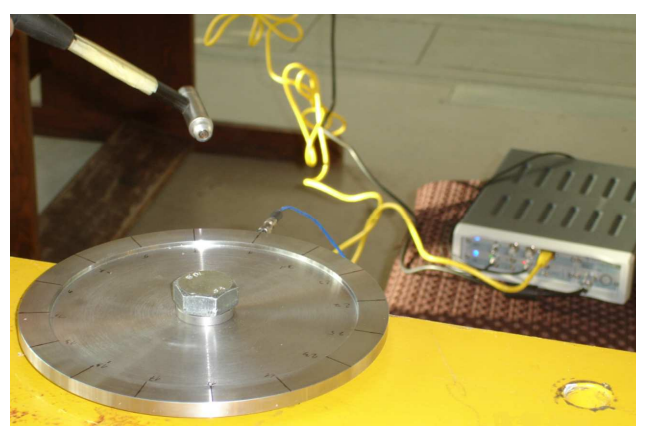

Tabela 8. Wyniki badań eksperymentalnych

Table 8. Results of the experimental investigation

\begin{tabular}{|c|c|c|c|c|c|c|c|}
\hline \multirow{2}{*}{ Lp. } & \multicolumn{7}{c|}{$n$} \\
\cline { 2 - 7 } & 2 & 3 & 4 & 5 & 6 & 7 & 8 \\
\hline \multicolumn{7}{|c|}{ Częstotliwości własne rozważanych obiektów $\omega_{n}$, Hz (dane eksperymentalne) } \\
\hline 1 & 11732 & 17215 & 22934 & 27451 & 31482 & 35206 & 39488 \\
\hline 6 & 8660 & 129438 & 168025 & 206181 & 252119 & 295506 & 341556 \\
\hline Błąd częstości $\varepsilon_{n}, \%$ (porównanie rozwiązań z modeli Timoshenki z wynikami eksperymentu) \\
\hline 1 & 226 & -529 & -922 & -728 & -420 & -084 & 052 \\
\hline 6 & -067 & -199 & 067 & 296 & 159 & 176 & 132 \\
\hline Błąd częstości $\varepsilon_{n}, \%$ (porównanie rozwiązań z modeli Bernoulliego z wynikami eksperymentu) \\
\hline 1 & 135 & -407 & -687 & -407 & -025 & 382 & 579 \\
\hline 6 & 043 & -1279 & -1282 & -818 & -411 & 285 & 1003 \\
\hline \multicolumn{7}{|c|}{ Błąd częstości $\varepsilon_{n}, \%$ (porównanie rozwiązań MES z wynikami eksperymentu) } \\
\hline 1 & -509 & 371 & -021 & -035 & 002 & 051 & -097 \\
\hline 6 & -308 & 197 & 201 & 226 & 002 & 015 & 015 \\
\hline
\end{tabular}


Eksperyment wykonano na obiektach nr 1 i 6 (tab. 1., rys. 2.). Dane techniczne materiału wykonanych próbek zawiera tab. 1 . W badaniach wykorzystano system pomiarowy LMS, składający się z młotka modalnego PCB - model $08 \mathrm{C} 03$ ze stalową końcówką, czujnika przyspieszenia PCB - model 353B18, systemu archiwizacji danych LMS SCADA oraz modułu pomiarowego SCM-V4E. Eksperyment zaplanowano i wykonano tak, aby wzbudzić i zidentyfikować częstości własne i odpowiadające im formy własne drgań giętnych w płaszczyźnie. Badane układy przymocowano połączeniem śrubowym do obiektu o znacznej masie i wymiarach gabarytowych (rys. 4.) Każdy badany obiekt pobudzano uderzeniem młotkiem modalnym w ten sam punkt. Odpowiedź układu mierzono w 32 punktach pomiarowych równo rozmieszczonych na obwodzie. Wartości wzbudzonych i zidentyfikowanych częstotliwości drgań własnych przedstawiono w tab. 8. Wartości te odniesiono do wyników wygenerowanych z modeli analitycznych i numerycznych MES badanych obiektów (tab. 1-5). W tabeli 8. pokazano także wartości błędu częstości (12), odnoszące się do otrzymanych modeli analitycznych i numerycznych obiektów. Jak należało się spodziewać, najgorsze rezultaty uzyskano dla obiektu nr 6, porównując wyniki uzyskane z modelu Bernoulliego (pierścień cienki) z wynikami badań doświadczalnych.

a)

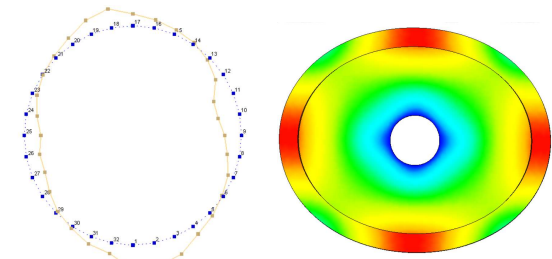

c)

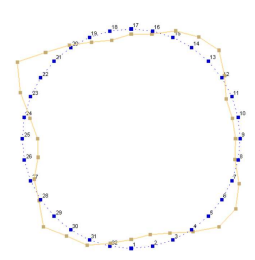

e)

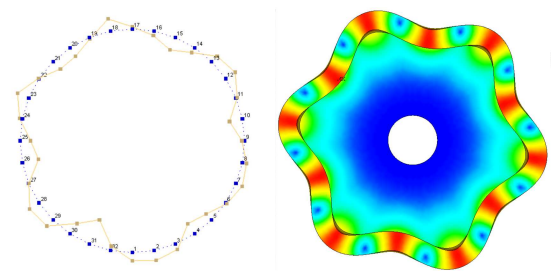

b)

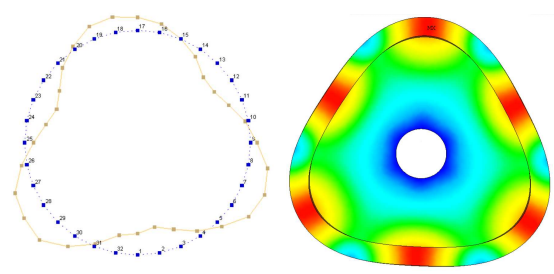

d)

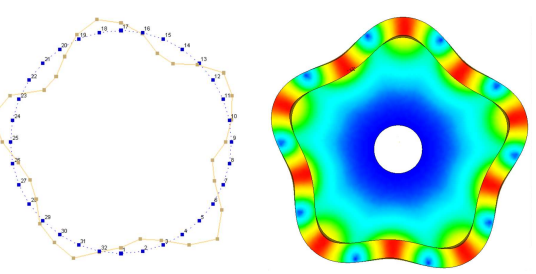

f)

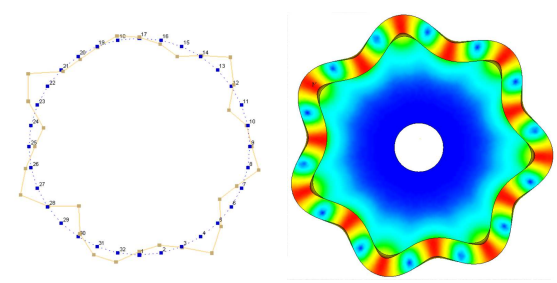

Rys. 5. Postacie drgań własnych odpowiadające częstościom: a) $\omega_{2}$, b) $\omega_{3}$, c) $\omega_{4}$, d) $\omega_{5}$, e) $\omega_{6}$, f) $\omega_{7}$

Fig. 5. Mode shapes related to the following frequencies: a) $\left.\left.\left.\left.\left.\omega_{2}, \mathrm{~b}\right) \omega_{3}, \mathrm{c}\right) \omega_{4}, \mathrm{~d}\right) \omega_{5}, \mathrm{e}\right) \omega_{6}, \mathrm{f}\right) \omega_{7}$ 
Rezultaty te sa nie do zaakceptowania. Dla tego obiektu współczynnik $h / R=018$. Pozostałe wyniki są zadowalające. Godny zauważenia jest wysoki poziom dopasowania wyników z modeli MES układów do rezultatów badań doświadczalnych (dwa ostatnie wiersze w tab. 8.). Jak wcześniej wspomniano, wyniki z modeli MES wykorzystano jako dane referencyjne do dostrajania modeli analitycznych badanych obiektów. Na rysunku 5. pokazano sześć postaci drgań giętnych w płaszczyźnie, odnoszących się do pierwszych sześciu częstości własnych, wyznaczonych w eksperymencie pomiarowym i z modelu MES dla pierwszego obiektu. Zauważa się znaczne podobieństwo kształtowe odpowiadających sobie form własnych.

\section{Uwagi i wnioski}

W pracy rozważano drgania giętne w płaszczyźnie, układów zawierających pierścień kołowy współpracujący z tarczą traktowaną jako podłoże sprężyste. Zaprezentowano modele analityczne drgań własnych pierścieni z warstwą sprężystą, opracowane na podstawie teorii pierścieni grubych (Timoshenki) i cienkich (Bernoulliego). W równaniach stosowano trzyparametrowy model warstwy sprężystej. Następnie omówiono zaproponowane modele MES tego typu układów. Wyniki rozwiązań MES wykorzystano do wyznaczenia współczynników modeli analitycznych omawianych układów. $Z$ analizy otrzymanych rezultatów wynika, że dla wartości współczynnika $h / R<014$ oba zaproponowane modele analityczne wykazują zadowalającą zgodność z wynikami z modeli MES. Otrzymane rozwiązania analityczne i numeryczne zweryfikowano badaniami doświadczalnymi dla dwóch reprezentatywnych obiektów. Prezentowane w pracy wyniki badań symulacyjnych i doświadczalnych potwierdzają celowość stosowania trzyparametrowego modelu warstwy sprężystej w modelach analitycznych. Ponadto warto zauważyć, że dla układów, w których współczynnik h/R < 014, wystarczające jest stosowanie w symulacji drgań modelu analitycznego pierścienia cienkiego (Bernoulliego), który charakteryzuje się znacznie prostszą formułą matematyczną $\mathrm{w}$ porównaniu z modelem pierścienia grubego.

\section{Podziękowanie}

Pracę poświęcam pamięci Profesora Romana Bogacza, mojego mentora i przyjaciela.

\section{Literatura}

[1] Liu Z., Zhou F., Oertel C., Wei Y.: Three-dimensional vibration of a ring with a noncircular cross-section on an elastic foundation, PIME Part C: J. Mech. Eng. Sci., 232 (2017) 2381-2393.

[2] Noga S.: Analityczne i numeryczne zagadnienia drgań układów z symetrią kołową, OW PRz, Rzeszów 2015. 
[3] Noga S.: Vibration analysis of a thin ring interacting with the annular plate treated as an elastic foundation, J. Civil. Eng. Environ. Architecture, 31 (2014) 131-138.

[4] Noga S., Bogacz R., Markowski T.: Vibration analysis of a wheel composed of a ring and a wheel-plate modelled as a three-parameter elastic foundation, J. Sound Vibration, 333 (2014) 6706-6722.

[5] Metrikine A., Tochilin M.: Steady-state vibrations of an elastic ring under a moving load, J. Sound Vibration, 232 (2000) 511-524.

[6] Noga S., Markowski T.: Vibration analysis of a thick ring interacting with the disk treated as an elastic foundation, Vibrations Physical System, 26 (2014) 217-222.

[7] Wang C., Ayalew B., Rhyne T., Cron S., Dailliez B.: Forced in-plane vibration of a thick ring on a unilateral elastic foundation, J. Sound Vibration, 380 (2016) 279-294.

[8] De Silva C.: Vibration and shock handbook, Taylor \& Francis, Boca Raton 2005.

\title{
IN-PLANE FLEXURAL VIBRATION OF WHEELS MODELLED BY RING SYSTEMS WITH ELASTIC FOUNDATION
}

\begin{abstract}
S u m m a r y
This paper deals with the in-plane flexural vibration of wheels, modelled as circular ring systems with elastic foundation. Equations of motion of discussed systems achieved on the basis of the Bernoulli and Timoshenko theory are presented. In motion equations the three-parameter Winkler elastic layer is included. Then for each model the frequency equation is derived and the equation of normal modes is given. The main part of the paper concerns the evaluation of the ring depth impact on the results of analytical solutions, which were obtained from the proposed analytical models. In the tuning process, of the coefficients of analytical models, the results of solutions achieved from finite element computations were used. Obtained simulation results were verified experimentally on selected objects. The cases of ring systems for which it is preferred to use the proposed analytical models were established.
\end{abstract}

Keywords: in-plane flexural vibration, Winkler elastic foundation

DOI: $10.7862 / \mathrm{rm} .2018 .42$

Otrzymano/received: 10.10 .2018

Zaakceptowano/accepted: 15.11 .2018 